\title{
CRITICAL LIBRARIANSHIP
}

Edited by Samantha Schmehl Hines and David Ketchum

ADVANCES IN LIBRARY ADMINISTRATION AND ORGANIZATION VOLUME 41 


\section{CRITICAL LIBRARIANSHIP}




\section{ADVANCES IN LIBRARY ADMINISTRATION AND ORGANIZATION}

\section{Series Editor: Samantha Schmehl Hines}

\section{Recent volumes:}

Volume 1: $\quad$ Edited by W. Carl Jackson, Bernard Kreissman and Gerard B. McCabe

Volumes 2-12: $\quad$ Edited by Bernard Kreissman and Gerard B. McCabe

Volumes 13-20: $\quad$ Edited by Edward D. Garten and Delmus E. Williams

Volume 21-24: $\quad$ Edited by Edward D. Garten, Delmus E. Williams and James M. Nyce

Volume 25: $\quad$ Edited by Edward D. Garten, Delmus E. Williams, James M. Nyce and Sanna Talja

Volume 26: $\quad$ Edited by Edward D. Garten, Delmus E. Williams, James M. Nyce and Janine Golden

Volume 27: $\quad$ Edited by William Graves III, James M. Nyce, Janine Golden and Delmus E. Williams

Volume 28: $\quad$ Edited by Delmus E. Williams, James M. Nyce and Janine Golden

Volume 29-32: $\quad$ Edited by Delmus E. Williams and Janine Golden

Volume 33: $\quad$ Edited by Delmus E. Williams, Janine Golden and Jennifer K. Sweeney

Volume 34: $\quad$ Edited by Samantha Schmehl Hines and Marcy Simons

Volume 35: $\quad$ Edited by David Baker and Wendy Evans

Volume 36: $\quad$ Edited by Samantha Schmehl Hines and Kathryn Moore Crowe

Volume 37: $\quad$ Edited by Samantha Schmehl Hines and Miriam Matteson

Volume 38: $\quad$ Edited by Samantha Schmehl Hines and Alice Daugherty

Volume 39: $\quad$ Edited by Samantha Schmehl Hines and George J. Fowler

Volume 40: $\quad$ Edited by Samantha Schmehl Hines and Janet A Crum 
ADVANCES IN LIBRARY ADMINISTRATION AND ORGANIZATION VOLUME 41

\title{
CRITICAL LIBRARIANSHIP
}

\author{
EDITED BY \\ SAMANTHA SCHMEHL HINES \\ Peninsula College, USA \\ DAVID H. KETCHUM \\ University of Oregon, USA
}

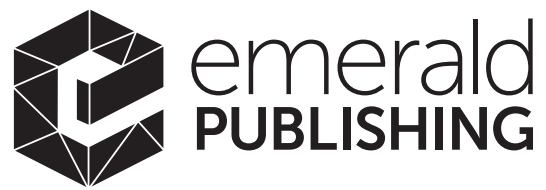

United Kingdom - North America - Japan

India - Malaysia - China 
Emerald Publishing Limited

Howard House, Wagon Lane, Bingley BD16 1WA, UK

First edition 2020

Chapter 6 @ 2020 Jade Alburo, Agnes K. Bradshaw, Ariana E. Santiago, Bonnie Smith, and Jennifer Vinopal. Published under an exclusive licence. Free to use for academic purposes.

All other Chapters and Editorial Matter (C) Emerald 2020

\section{Reprints and permissions service}

Contact: permissions@emeraldinsight.com

No part of this book may be reproduced, stored in a retrieval system, transmitted in any form or by any means electronic, mechanical, photocopying, recording or otherwise without either the prior written permission of the publisher or a licence permitting restricted copying issued in the UK by The Copyright Licensing Agency and in the USA by The Copyright Clearance Center. Any opinions expressed in the chapters are those of the authors. Whilst Emerald makes every effort to ensure the quality and accuracy of its content, Emerald makes no representation implied or otherwise, as to the chapters' suitability and application and disclaims any warranties, express or implied, to their use.

\section{British Library Cataloguing in Publication Data}

A catalogue record for this book is available from the British Library

ISBN: 978-1-83909-485-9 (Print)

ISBN: 978-1-83909-484-2 (Online)

ISBN: 978-1-83909-486-6 (Epub)

ISSN: 0732-0671 (Series)

\section{ISOQAR certified}

Management System,

awarded to Emerald

for adherence to

Environmental

standard

ISOQAR

ISO 14001:2004 


\section{CONTENTS}

List of Contributors

$v i i$

Introduction: Critical Librarianship

David H. Ketchum

Theoretical and Practical Implications of Power Dynamics in Academic Libraries

Lilian Oyieke

Widening Participation Praxis and Library Leadership Andrew Preater

Feminists at Work: Organizational Leadership in Academic Libraries

Freeda Brook and Martinique Hallerduff

From Street-level Bureaucracy to Sustainable Communities:

Librarianship for Social Justice in Times of Limited Resources

Yolanda Patrice Jones

Looking Beyond Libraries for Inclusive Recruitment and Retention Practices: Four Successful Approaches

Jade Alburo, Agnes K. Bradshaw, Ariana E. Santiago,

Bonnie Smith, and Jennifer Vinopal

Countering Conformity: Embracing the "Other" and Supporting Employees with High-functioning Autism in Canadian Academic Libraries

Lori Giles-Smith and Emma Popowich

Going Back to Work: How Supervisors Can Support New Mothers as They Transition Back to the Library

Emily A. B. Swanson 
Teamwork, Emotional Intelligence, and the Skills Organizations Need Now

John A. Lehner

Author Biographies

Index 


\section{LIST OF CONTRIBUTORS}

Jade Alburo

Agnes K. Bradshaw

Freeda Brook

Lori Giles-Smith

Martinique Hallerduff

Yolanda Patrice Jones

David H. Ketchum

John A. Lehner

Lilian Oyieke

Emma Popowich

Andrew Preater

Ariana E. Santiago

Bonnie Smith

Emily A. B. Swanson

Jennifer Vinopal
University of California, Los Angeles, USA

Virginia Commonwealth University Libraries, USA

Luther College, USA

University of Manitoba, Canada

Oakton Community College, USA

Florida A\&M University College of Law, USA

University of Oregon, USA

University of Houston, USA

The Technical University of Kenya, Kenya

University of Manitoba, Canada

University of West London, UK

University of Houston, USA

University of Florida, USA

Giovale Library, Westminster College, USA

The Ohio State University, USA 
This page intentionally left blank 


\title{
INTRODUCTION: CRITICAL LIBRARIANSHIP
}

\author{
David H. Ketchum
}

While critical theory has roots in the social sciences and humanities, it moves beyond attempts to merely understand and explain society, challenging individuals and institutions to critique and perhaps change the social constructs in which we live, particularly those that contribute to social injustice. More specifically, critical theory acknowledges that racism, patriarchy, capitalism, and similar systems of power and oppression have become nearly inextricable from many aspects of Western culture, largely due to centuries of dominance by white, heterosexual, Christian males. This centralization of power led to the marginalization of "others," or those who do not belong to the dominant factions within society. Despite this, proponents of critical theory insist that ideology is the main impediment to human liberation, and liberation is achievable by interrogating and dismantling tyrannical ideologies and their effects on society.

Critical theory is not new. Critical Theory as a school of thought emerged in Germany in the 1930s, and has since been applied widely and in varying contexts. As aspects of Critical Theory were more broadly adopted and applied, "critical theory" became colloquialized and critical practices embedded in many professions and activities. Examples of this include critical pedagogy, critical management, critical anthropology, and critical librarianship. The primary commonalities within these movements are a conscious effort and interest in looking reflectively at the values, practices, and structures within pedagogy, management, librarianship, etc., and changing those things that contribute to social, economic, and other injustices.

Sanford Berman (born October 6, 1933) is known extensively in the library cataloging community as an activist and proponent of alternative library practices. He is perhaps most well known for his criticism of bias in Library of Congress (LOC) subject headings. In 2007, Berman submitted a formal recommendation to the LOC Cataloging Policy and Support Office to have "critical librarianship" added as a LOC subject heading. Within this proposal,

\footnotetext{
Critical Librarianship

Advances in Library Administration and Organization, Volume 41, 1-3

Copyright (C) 2020 Emerald Publishing Limited

All rights of reproduction in any form reserved

ISSN: 0732-0671/doi:10.1108/S0732-067120200000041001
} 
Berman (2007) recommends the subject heading be applied to works of libraryrelated literature where "considerations for the human condition and for human rights take precedence over other professional concerns." This subject heading was yet to be added at the time of this publication. Despite this ongoing omission, I agree with Garcia (2015) in his assertion that this act was an overt attempt by a library professional to formally place "librarianship within a critical theorist framework that is epistemological, self-reflective, and activist in nature."

The term and concept of "critical librarianship" emerged fairly recently within our long professional history, but librarians have most certainly been practicing critical librarianship without a label or definition for a very long time. Indeed, since their beginnings in the mid-nineteenth century, public libraries in the United States have sought to provide citizens with free and equitable access to information resources. Prior to this, print literature was generally inaccessible to women, laypeople, and those lacking wealth, formal education, and other social privileges of the time. The demand for access was so great that, by 1920, more than 3,500 free public libraries were built throughout the United States (Brady \& Abbot, 2015). Free and open access to information provided individuals and groups an opportunity to self-educate, obtain information resources that reflect multiple perspectives, and become more autonomous and empowered citizens. This expansion of access to information resources quickly became synonymous with - and considered necessary for - America's enduring democracy. In 1939, the American Library Association (ALA) published the Library Bill of Rights; still endorsed and maintained by ALA (most recently amended on January 19, 2019), this document outlines library patrons' rights to intellectual freedom, and the roles of librarians in supporting those rights. Examples include: resources should be provided for the enlightenment of all people; material should present all views on current and historic issues; libraries should challenge censorship and collaborate with others who resist abridgement of free access to information; a person's right to use the library cannot be denied due to origin, age, background, or point of view; and libraries should advocate for and protect user privacy (ALA, 1939).

Arguably, critical theory was already being applied by librarians when this concept was first being articulated by philosophers and theorists in the Western world, as a natural outcome of our professional values and responsibilities. In fact, "Critical librarianship has always been embedded in the library profession" (Garcia, 2015). Despite this, libraries are not immune to ideologies that allow for the marginalization and oppression of others. Indeed, "Libraries, like all institutions [in Western culture] are produced in and through systems marked by racism, patriarchy, and capitalist modes of production" (Drabinski, 2019, p. 49). Because of our professional values and the role of libraries within our society, however, librarians are well equipped for questioning power structures within our organizations and actively changing work practices that maintain preference and privilege for those who have historically held consolidated power within our society and places of work.

As Farkas (2017) notes, "critical librarianship has become a force that pervades every area of our work." Again, this is unsurprising since the concepts of 
critical theory are inherent in our professional values. One aspect of librarianship that has been underexplored in this movement, however, is library management. This volume of Advances in Library Administration and Organization intends to help fill this gap in professional literature by providing evidence of applied critical theory in the administration and organization of libraries. Chapters demonstrate how library leaders have applied feminist theory in the management of their organizations, challenged antiquated hiring practices that perpetuate the subjugation of entire groups of people and provided practical solutions for changing course, encouraged librarians to question power dynamics between themselves and library users, and more. Each chapter demonstrates how critical theory has been or can be pragmatically applied in libraries, offering readers an opportunity to learn more about the critical librarianship movement while actively challenging and dismantling structures that perpetuate inequality within and outside our places of work.

\section{REFERENCES}

American Library Association. (1939, June 19). Library Bill of Rights. Retrieved from http:// www.ala.org/advocacy/intfreedom/librarybill. Accessed on January 15, 2020.

Berman, S. (2007, May 16). Letter to cataloging policy \& support office, Library of Congress [PDF]. Retrieved from http://www.sanfordberman.org/headings/critical.pdf

Brady, H., \& Abbot, F. (2015). A history of US Public Libraries [online exhibit], Digital Public Library of America. Retrieved from https://dp.la/exhibitions/history-us-public-libraries. Accessed on January15, 2020.

Drabinski, E. (2019). What is critical about critical librarianship? Art Libraries Journal, 44(2), 49-57.

Fakas, M. (2017). Never neutral. American Libraries, 48(1/2), 70.

Garcia, K. (2015, June 19). Keeping up with...critical librarianship. American Library Association. Retrieved from http://www.ala.org/acrl/publications/keeping_up_with/critlib 
This page intentionally left blank 


\title{
THEORETICAL AND PRACTICAL IMPLICATIONS OF POWER DYNAMICS IN ACADEMIC LIBRARIES
}

\author{
Lilian Oyieke
}

\begin{abstract}
Discourses on critical librarianship have been mainly theoretical. However, discourses with a practical application of Critical Theory in librarianship, critical librarianship, or library management and operations are limited. Yet, librarianship underscores efficiency and practicality in service provision with the dominant ideology in librarianship being practicality. Based on Critical Theory and emerging power dynamics in e-services, this chapter presents a discussion on the practical application of Critical Theory in academic libraries. The Web 2.0 technologies have triggered a shift in information seeking and use by empowering the academic library users to seek and use information from nontraditional sources. This shift in information seeking behavior and the resultant power dynamics has an impact on strengthening of the academic library as a public sphere; a public virtual space where people can meet and exchange ideas with the eventual outcome of democratization of knowledge. This chapter analyses the practical implications of power dynamics in academic libraries and the need for realignment of academic library functions to key Critical Success Factors (CSFs) including the role of library management, a focus on librarian power, a focus on user empowerment, creating awareness of the Web 2.0 services, and maximizing the use of Web 2.0 technologies. A proper realignment of the shifting power is necessary and must be pursued as a deliberate strategy by academic libraries to facilitate generation and sharing of information. It concludes by presenting the practical
\end{abstract}

\section{Critical Librarianship}

Advances in Library Administration and Organization, Volume 41, 5-20

Copyright (C) 2020 Emerald Publishing Limited

All rights of reproduction in any form reserved

ISSN: 0732-0671/doi:10.1108/S0732-067120200000041002 
implications of power dynamics in academic libraries and recommendations on dealing with the emerging paradigm shifts.

Keywords: Web 2.0; academic library; power dynamics; public sphere; librarian power; critical theory

\section{INTRODUCTION}

Maximizing the use of Web 2.0 technologies in academic libraries should be the backbone of knowledge creation and sharing practices in academic libraries. Web 2.0 refers to the development of online services that encourage collaboration, communication, and sharing of information (Naqvi, 2012). It is a term often applied to a perceived ongoing transition of the World Wide Web from a collection of websites to a full-fledged computing platform serving web applications to end users (O'Reilly, 2007). It serves as a platform that spans all connected devices. The technology infrastructure of Web 2.0 is complex, constantly in flux, and actually in a renaissance mode. It includes server software, content syndication, messaging protocols, standards-based browsers, and various client applications (Chua \& Goh, 2010; Fuchs, 2011; O’Reilly, 2007). Web 2.0 technologies enable real-time transfer of knowledge in academic libraries. Specifically, Web 2.0 technologies represent new forms of public spheres (Papacharissi, 2002). They make academic libraries new kinds of public spheres, in which both academic librarians and users are active participants.

The idea of a public sphere, originally conceptualized by Habermas, refers to a realm of an individual's social life in which public opinion can be formed on all matters oriented to the common good and where access is guaranteed to all citizens (Habermas, 1989; Sinekopova, 2006). In public institutions such as universities, access to information to form opinions and strengthen the public sphere principally involves the academic library (Buschman, 2003). When library users $\log$ onto Web 2.0 technologies such as Facebook, Twitter, wikis, or blogs and engage in discussions with librarians, their friends, and followers, they are in effect participating in these new kinds of public spheres. At the same time, academic librarians are now utilizing various Web 2.0 technologies to engage with their users, colleagues, and for their information work. For instance, the use of live chat, wikis, or blogs are all examples of new kinds of public spheres where academic librarians and library users participate.

Historically, libraries have possessed power as the main custodians of information and knowledge resources (Thompson, 1974; Wilson, 1968). However, in the current dispensation they are hardly acknowledged as part of the information revolution or central to the knowledge society where the profusion of resources and the promise of a more informed citizenry require the ability to access and use information effectively (Kranich, 2001; Tise, 2012). These are emerging challenges for modern-day libraries and librarians; that they are now more than ever expected to empower members of their user communities through training and information skills. These skills, some argue, empower 
library users and make it possible for them to participate effectively in the knowledge society (Kranich, 2001; Tise, 2012).

\section{LIBRARIAN POWER}

Traditionally, the power of librarians as professionals has been their expertise, skills, and control of access to information and knowledge resources and of meeting library user needs (Thompson, 1974; Wilson, 1968). Librarian power can be exercised through offering user training programs which empower users to, for example, access authoritative information resources. Librarians need to be aware of this power and utilize it.

Librarians gain power by exercising bibliographic control (Thompson, 1974; Wilson, 1968). Wilson (1968) identified two kinds of librarian power, namely, exploitative and descriptive. Librarian power was evident in exploitative and descriptive control, and the way that librarians determined and selected various library service offerings for their users (Freidson, 1986; Wilson, 1968).

Prior to the Web 2.0 technologies, academic librarians also had a greater degree of power such as limiting services to opening hours as determined by the library management. Situations like these, where academic library users rely on librarians for access to information, can be described as examples of librarian power. Foucault (1982) defines power as a relation:

[A] power relationship can only be articulated on the basis of two elements which are indispensable if it is really to be a power relationship: that "the other" (the one over whom power is exercised) be thoroughly recognized and maintained to the very end as a person who acts; and that, faced with a relationship of power, a whole field of responses, reactions, results, and possible inventions may open up (p. 789)

Foucault identifies various forms of power including sovereign power, disciplinary power, pastoral power, and power-knowledge. According to Foucault's understanding of power-knowledge, knowledge is always an exercise of power and power always a function of knowledge (Foucault, 1982). Knowledge is never neutral, as it determines relations. The academic librarian's power-knowledge appears to be increasingly under threat in the Web 2.0 environment, and this can destabilize relations with library users.

The academic librarians' power relations with users were based strongly on the special kind of knowledge that they possessed and applied (Kogan, 2005). For instance, reference services traditionally involved direct face-to-face contact between the librarian and the library user. A library user with an information need would consult a reference librarian for assistance on identification of relevant information resources. In such a case, the librarian exercised a kind of exploitative power that Wilson explains as a "power that could supply the best reading resources to meet the needs of any library user" (1968, p. 34).

Today, the Web 2.0 technologies provide library users with exploitative power. For example, in a Web 2.0 environment library users with information skills can independently source the best information resources to meet their needs 
without the assistance of the reference librarian. This can be done through sharing information about such resources with other users connected through the Web 2.0 technologies.

Descriptive power, on the other hand, is expressed through the "aboutness" of a document (Wilson, 1968). Aboutness is closely related to theories of meaning, interpretation, and epistemology (Hjørland, 2001). For example, when library users log onto Web 2.0 platforms to share information and knowledge, they may use social tagging to bring together the tags from a group of people for improved retrieval and in order to foster relationships between the users. This demonstrates how Web 2.0 technologies are radically changing the production, distribution, evaluation, and use of knowledge (Harrison \& Barthel, 2009).

\section{USER EMPOWERMENT}

Empowerment is fundamentally about gaining power. It carries the idea that people should be enabled to take control themselves (Pruijt \& Yerkes, 2014). User empowerment appears to challenge librarian power. Web 2.0 technologies have empowering effects for academic library users (Oyieke, 2015). They provide alternative means of accessing information resources through sharing links to open access e-databases, as well as bits and pieces of knowledge that can be readily obtained through user participation on various Web 2.0 platforms.

The Web 2.0 technologies empower academic library users who, from remote locations, have access to library services and information resources (Aqil, Ahmad, \& Siddique, 2012). This kind of user empowerment is perceived by academic librarians as diminishing their power as intermediaries in the information seeking and retrieval process (Liu, 2008). It navigates on whether indeed librarian power is diminishing, making it worth investigating how they can adapt to the new environment to mediate these power shifts, and how they can reposition themselves in this changing environment (Lor, 2018).

\section{ACADEMIC LIBRARIES AS PUBLIC SPHERES}

Academic libraries have traditionally enabled and facilitated the exchange and growth of information, knowledge, and a culture of learning among faculty, students, and the general public. Academic libraries as public spheres are affected by the increasing commodification of information that impact on their democratic functions, such as access to the Internet (Fleissner, 2009). They have been transformed into a different kind of space filled with networked places such as urban Wi-Fi hotspots and created forms of public sphere (Castells, 2000). By building diverse voices, perspectives, and arguments into library collections and services, librarians can keep the democratic ideals alive (Buckland, 2003).

The Lyon Declaration principles (2014) reinstate that access to information, and the ability to understand, use, and share it, is necessary for the promotion of democratic societies. In this sense, academic libraries represent a focal point of 